\title{
保水性を付与した廃ガラス発泡骨材ポーラスコンクリートの 緑化基盤材への適用
}

\author{
村上聖 ${ }^{* 1}$ 武田浩二 ${ }^{* 1}$ 山口信 ${ }^{* 1}$ 佐藤あゆみ ${ }^{* 1}$ \\ *1 熊本大学 大学院自然科学研究科 ( $=860-8555$ 熊本県熊本市中央区黒髪 2-39-1)
}

\begin{abstract}
要旨：本研究ではリサイクル資材による生物対応型エコマテリアルの開発を主眼に、屋上緑化基盤として の廃ガラス発泡骨材を用いたポーラスコンクリートの基礎物性試験ならびに芝の植生試験を行い、その適 用性について実験的検討が行われた。基礎物性としては、空隙率、圧縮強度㧍よび赤外線ランプ照射試験 による保水性が調べられた。その結果として廃ガラス発泡骨材ポーラスコンクリートは、圧縮強度は小さ いが、超軽量により屋上積載荷重の軽減がはかられること、ゼオライト骨材ポーラスコンクリートを保水 層とする 2 層構造板により保水性が向上し、芝草丈の成長量増加に効果を有することなどが分かった。
\end{abstract}

キーワード：屋上緑化、廃ガラス発泡骨材、ゼオライト骨材、空隙率、圧縮強度、保水性、植生

\section{1. はじめに}

ポーラスコンクリートは、内部に多数の連続空隙を有 するために、生物対応型エコマテリアルとして期待され ている。ここで研究対象の屋上緑化ポーラスコンクリー 卜は、粗骨材に廃ガラス発泡軽量骨材を使用し、軽量化 による屋上の積載荷重軽減に資することを目的としてい る。また、屋上緑化では日射による水分の蒸散が激しい ため十分な灌水が要求されるが、ポーラスコンクリート 自体にある程度保水性を付与することにより灌水設備の 簡略化も期待される。そこで本研究では廃ガラス発泡骨 材ポーラスコンクリートを用い、ポーラスコンクリート の保水性を確保するための各種保水層の提案と保水性が 芝植生効果に及ぼす影響について実験的検討を行った。

\section{2. 実験方法}

\section{1 使用材料}

Table 1 に本実験の使用材料を示す。セメントには、 植生を考慮し、高炉セメント B 種を用いた。粗骨材に は、廃ガラス発泡骨材と比較のために砕石 5 号を用い た。また、廃ガラス発泡骨材ポーラスコンクリートの下 部に保水層を設け、その保水層として吸水率が約 $40 \%$ の天然ゼオライト(モルデナイト鉱)を骨材としてポーラ スコンクリートを作製した。な打、ゼオライト骨材には 表中に示す 2 水準の粒径のものを用い、JIS に準拠して 骨材試験を行った。また、セメントペーストにプレミッ クスするタイプの保水材として、木炭粉末抢よびパルプ スラッジ焼却灰(以下、PS 灰と称する)を用いた。セメ ントペーストの流動性の調整には、ポリカルボン酸系の 高性能 $\mathrm{AE}$ 減水剤を用いた。
Table 1 Materials used in this study

\begin{tabular}{|c|c|}
\hline Cement & $\begin{array}{l}\text { Portland blast-furnace slag cement (Type B) } \\
\text { Density }: 3.03 \mathrm{~g} / \mathrm{cm}^{3}\end{array}$ \\
\hline $\begin{array}{l}\text { Coarse } \\
\text { aggregate }\end{array}$ & $\begin{array}{l}\text { Waste glass foam } \\
\text { Surface-dry density }: 0.832 \mathrm{~g} / \mathrm{cm}^{3} \\
\text { Water absorption }: 44.1 \% \\
\text { Oven-dry density : } 0.465 \mathrm{~g} / \mathrm{cm}^{3} \\
\text { Percentage of solid volume }: 63.0 \% \\
\text { Grain size }: 10 \sim 20 \mathrm{~mm} \\
\text { Crushed stone No.5 } \\
\text { Surface-dry density : } 2.95 \mathrm{~g} / \mathrm{cm}^{3} \\
\text { Water absorption }: 0.63 \% \\
\text { Oven-dry density }: 2.93 \mathrm{~g} / \mathrm{cm}^{3} \\
\text { Percentage of solid volume }: 55.7 \%\end{array}$ \\
\hline $\begin{array}{l}\text { Aggregate } \\
\text { used for } \\
\text { water } \\
\text { retention }\end{array}$ & $\begin{array}{l}\text { Zeolite A } \\
\text { Surface-dry density }: 1.63 \mathrm{~g} / \mathrm{cm}^{3} \\
\text { Water absorption }: 41.4 \% \\
\text { Oven-dry density }: 0.955 \mathrm{~g} / \mathrm{cm}^{3} \\
\text { Fineness modulus }: 3.51 \\
\text { Maximum size }: 2.5 \mathrm{~mm} \\
\text { Percentage of solid volume }: 59.3 \% \\
\text { Zeolite B } \\
\text { Surface-dry density }: 1.63 \mathrm{~g} / \mathrm{cm}^{3} \\
\text { Water absorption }: 42.4 \% \\
\text { Oven-dry density }: 0.939 \mathrm{~g} / \mathrm{cm}^{3} \\
\text { Fineness modulus }: 6.26 \\
\text { Maximum size }: 15 \mathrm{~mm} \\
\text { Percentage of solid volume }: 62.9 \%\end{array}$ \\
\hline $\begin{array}{l}\text { Admixture } \\
\text { used for } \\
\text { water } \\
\text { retention }\end{array}$ & $\begin{array}{l}\text { Charcoal powder } \\
\text { Oven-dry density : } 0.38 \mathrm{~g} / \mathrm{cm}^{3} \\
\text { Water absorption }: 189 \% \\
\text { Pulp sludge ash } \\
\text { Oven-dry density }: 2.31 \mathrm{~g} / \mathrm{cm}^{3}\end{array}$ \\
\hline $\begin{array}{l}\text { Chemical } \\
\text { admixture }\end{array}$ & $\begin{array}{l}\text { Superplasticizer } \\
\text { Poly-carboxylic acid type }\end{array}$ \\
\hline
\end{tabular}




\section{2 ポーラスコンクリートの使用調合}

Table 2 に各種ポーラスコンクリートの使用調合を示 す。なお、使用骨材のうち、比較用の砕石 5 号は表乾状態、 廃ガラス発泡骨材およびゼオライト骨材は気乾状態でそ れぞれ使用した。また、保水材の木炭粉末および PS 灰 は絶乾状態で用いた。

粗骨材に比較用の砕石 5 号を用いた場合には、水セ メント比を $\mathrm{W} / \mathrm{C}=25 \%$ 、目標空隙率を 30 \% 一定とし、 保水材無混入、木炭粉末をセメント質量の $10 \%$ で混入 および PS 灰をセメント質量の $20 \%$ で混入の 3 種類に ついてポーラスコンクリートを作製した。なお、木炭粉 末および PS 灰の混入率については、外割混入のため目 標空隙率 30 \%を大きく下回らない限度として定めた。 また、保水材をセメントペーストにプレミックスする場 合、混練時の保水材による吸水のため所要のセメント ペーストの流動性を確保すること（フロー值 180～200） が難しく、これに関しては予備実験を通じて、木炭粉末 使用の場合、木炭吸水量の $2 / 3$ の水を単位水量に加算、 PS 灰使用の場合には PS 灰質量の $1 / 2$ の水を単位水量 に加算し、混練時の木炭粉末および PS 灰の吸水を考慮 した。なお、上記の加水量は、流動性の確保と同時にセ メントペーストの垂れを生じない限度として決定し、良 好な練り上がり状態になることを確認した。

廃ガラス発泡骨材を用いた場合は、水セメント比を $\mathrm{W} / \mathrm{C}=20 \%$ 、目標空隙率を $20 \%$ とし、骨材吸水量の $1 / 3$ の水を単位水量に加算した。また、最大寸法 $15 \mathrm{~mm}$ のゼオライト骨材 (以下、ゼオライト骨材 B と称する) 使用の場合は、水セメント比を $\mathrm{W} / \mathrm{C}=20 \%$ 、目標空 隙率を $20 \%$ とし、骨材吸水量を単位水量に加算、最大 寸法 $2.5 \mathrm{~mm}$ のゼオライト骨材 (以下、ゼオライト骨材 $\mathrm{A}$ と称する)使用の場合には、水セメント比を $\mathrm{W} / \mathrm{C}=$ $40 \%$ 、目標空隙率を $20 \%$ とし、骨材吸水量の $2 / 3$ の 水を単位水量に加算した。なお、上記の加水量は、廃ガ ラス発泡骨材およびゼオライト骨材の混練時の吸水に対 するセメントペーストの流動性の確保と同時にセメント ペーストの垂れを生じない限度として決定し、これらの 調合については、事前の試し練りにより良好な練り上が り状態になることを確認した。
各種ポーラスコンクリートの練混ぜ方法については、 砕石 5 号を用いた場合は、容量 $55 \mathrm{~L}$ の強制攪拌型 2 軸 ミキサーを用い、廃ガラス発泡骨材およびゼオライト骨 材使用の場合には、強制攪拌型ミキサーでは骨材の破損 を生じるために、容量 30L のオムニミキサーを使用し、 セメント、骨材 (十木炭粉末、PS 灰)をミキサーへ投入 ᄂ 30 秒間空練り後、水 (+高性能 AE 減水剂)を投入し て 2 分間の練混ぜを行った。

\section{3 試験方法}

ポーラスコンクリートの空隙率および圧縮強度試験に は、直径 $100 \mathrm{~mm} \times$ 高さ $200 \mathrm{~mm}$ の円柱供試体を各 3 個 ずつ作製し、標準養生材齢 28 日後、各試験に供した。 なお、供試体の締固めは突き棒と木づちを用いて行っ た。また、空隙率試験は日本コンクリート工学会の「ポー ラスコンクリートの空隙率試験方法(案)」1)の容積法に 準拠して行い、圧縮強度試験では供試体両面をセメント ペーストでキャッピングを行った。

屋上緑化に供することを目的に、日射による水分蒸散 をシミュレートするために、赤外線ランプ照射による保 水性試験を行った。Fig. 1 に保水性試験に供したポーラ スコンクリート板の形状寸法を示す。試験体寸法は 400 $\times 400 \times 60 \mathrm{~mm}$ の平板とし、Table 2 に示す全調合につ いて各 1 体ずつ作製した。また、Fig. 1 に示すように、 廃ガラス発泡骨材ポーラスコンクリートの下部に保水層 として 2 種類のゼオライト骨材を用いたポーラスコン クリートを 2 層構造とした試験体を作製した。その作 製は、最初にゼオライト骨材ポーラスコンクリートを厚 さ $20 \mathrm{~mm}$ で打設し、その上に廃ガラス発泡骨材ポーラ スコンクリートを打ち重ねる方法で 2 層構造板とした。 なお、試験体の締固めは角材を用いたタッピングにより 行い、材齢 28 日まで現場湿布養生を行った。

保水性試験は Fig. 1 の試験体を用い、次の手順で実 施した。

a) 試験体を 24 時間 $20{ }^{\circ} \mathrm{C}$ 水中浸漬後、水中から取り 出し十分に水切りを行った後に湿布で包み 1 時間 気中放置し、内部から水が浸み出ることなく、表面 の水膜を拭い去った状態 (ここでは表乾状態と記す) にして赤外線ランプ照射試験に供した。

Table 2 Mix proportions of porous concretes

\begin{tabular}{|c|c|c|c|c|c|c|c|c|}
\hline \multirow{2}{*}{ Type of aggregate } & \multirow{2}{*}{$\begin{array}{l}W / C \\
(\%)\end{array}$} & \multirow{2}{*}{$\begin{array}{c}\text { Specified } \\
\text { void ratio } \\
(\%)\end{array}$} & \multirow{2}{*}{$\begin{array}{l}\text { Admixture used } \\
\text { for water } \\
\text { retention }\end{array}$} & \multicolumn{4}{|c|}{ Unit content $\left(\mathrm{kg} / \mathrm{m}^{3}\right)$} & \multirow{2}{*}{$\begin{array}{c}S p / C \\
(\%)\end{array}$} \\
\hline & & & & $C$ & $W$ & G & $A d$ & \\
\hline \multirow{3}{*}{$\begin{array}{l}\text { Crushed stone } \\
\text { No. } 5\end{array}$} & 25 & 30 & - & 266 & 67 & 1,610 & - & 0.5 \\
\hline & 25 & 30 & Charcoal powder & 266 & $67+34$ & 1,610 & 27 & 0.5 \\
\hline & 25 & 30 & Pulp sludge ash & 266 & $67+27$ & 1,610 & 53 & 0.5 \\
\hline Waste glass foam & 20 & 20 & - & 344 & $69+42$ & 287 & - & - \\
\hline Zeolite B & 20 & 20 & - & 346 & $69+245$ & 579 & - & - \\
\hline Zeolite A & 40 & 20 & - & 300 & $120+153$ & 555 & - & - \\
\hline
\end{tabular}

W/C : Water-cement ratio, C : Cement, W : Water, G : Coarse aggregate, Ad : Admixture used for water retention, $\mathrm{Sp}:$ Superplasticizer 


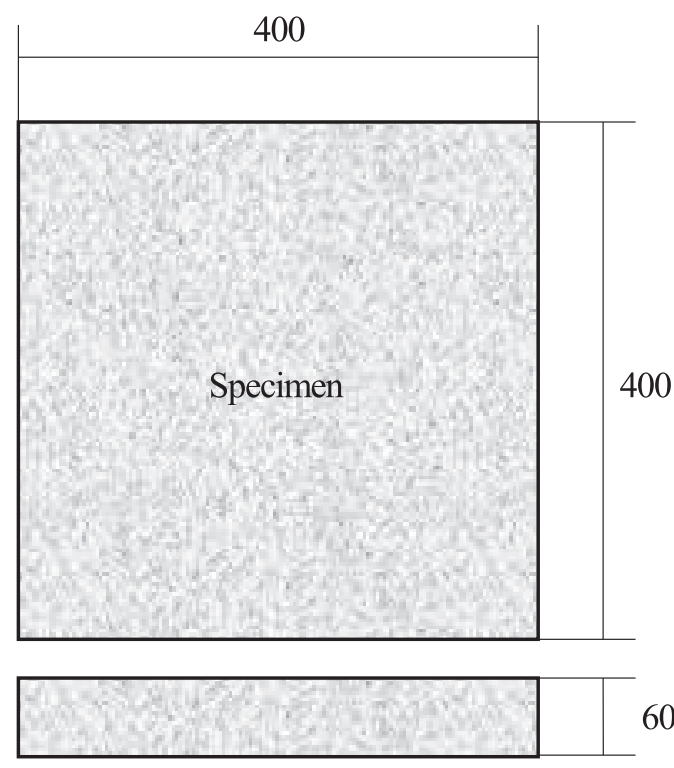

Porous concretes with crushed stone, waste glass foam, zeolite A and B used

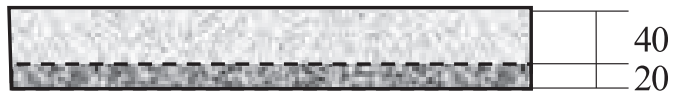

Porous concrete composed of waste glass foam (upper) and zeolite A or B (lower)

Fig. 1 Specimens supplied to water retention test series

b） Fig. 2 に示すように試験体の赤外線ランプ照射面以 外の面を厚さ $50 \mathrm{~mm}$ のスタイロフォームで囲み、そ れを電子天秤の上に載せ、赤外線ランプ照射 24 時 間までの試験体質量を所定の時間間隔で自動計測し た。赤外線ランプは、試験体上面から高さ $27 \mathrm{~cm}$ の 位置にランプ先端がくるように板中央に設置し、室 温は $26{ }^{\circ} \mathrm{C}$ 一定とした。なお、湿度は成り行きである が、ほぼ同時期に試験を実施した。なお、赤外線ラ ンプ照射試験について規格試験がない現状で、試験 詳細は試行錯誤によるものであることを付記する。

c）赤外線ランプ照射試験終了後、試験体を 24 時間以 上 $110{ }^{\circ} \mathrm{C}$ の乾燥機に入れ、絶乾質量を測定した。 初期保水量 $\left(\mathrm{g} / \mathrm{cm}^{3}\right)$ は、保水性コンクリートブロッ クの品質性能規格 ${ }^{2}$ にに合わせ、(表乾質量一絶乾質 量) /(試験体体積)で、また保水率 $(\%)$ を初期保水 量に対する経時保水量の百分率として求め、保水性 能の評価指標として用いた。

芝植栽試験用試験体には、Fig. 1 の試験体のうち、砕 石 5 号骨材ポーラスコンクリート、木炭粉末および PS 灰混入砕石 5 号骨材ポーラスコンクリート、廃ガラス 発泡骨材ポーラスコンクリート(なお、これらの板厚は $100 \mathrm{~mm}$ とした)、ならびに廃ガラス発泡骨材ポーラス コンクリートとゼオライト骨材 B ポーラスコンクリー トの 2 層構造板 (なお、前者の板厚を $70 \mathrm{~mm}$ 、後者の板 厚を $30 \mathrm{~mm}$ 、総厚は $100 \mathrm{~mm}$ とした)、比較として川砂

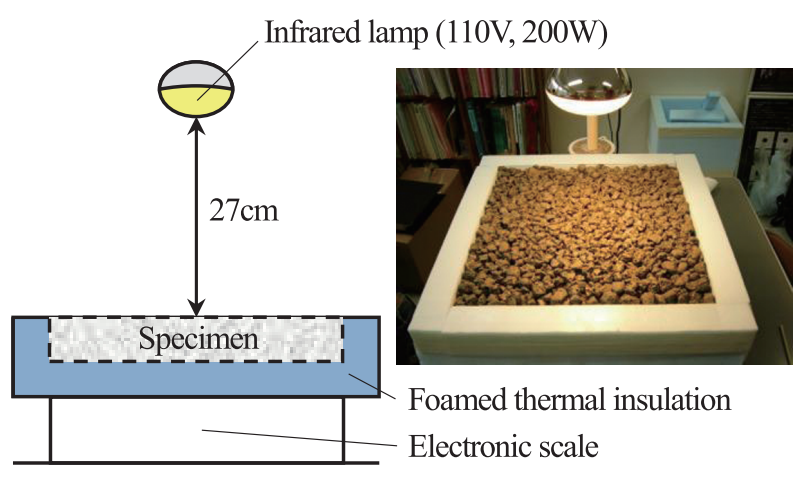

Fig. 2 Water retention test by means of infrared irradiation

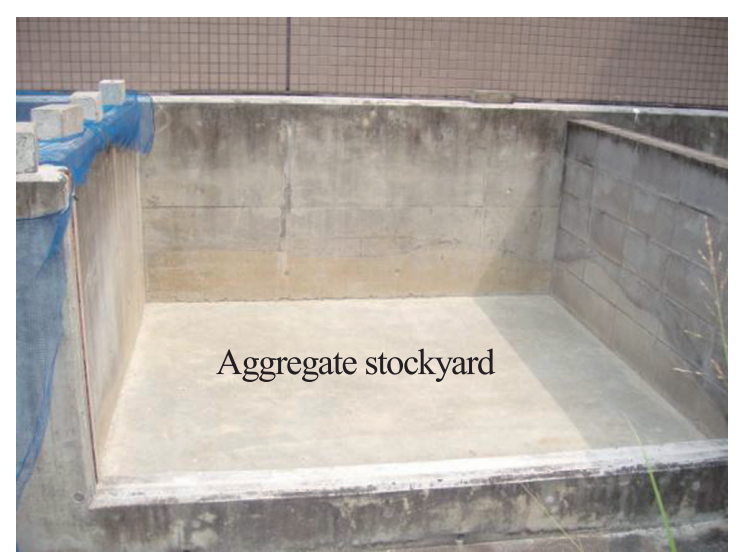

Photo. 1 Setting place of planting specimens

を厚さ $100 \mathrm{~mm}$ で敷き詰めたものを用い、培養土に西洋 芝種子を 20L：1dL の割合で混合したものを試験体上面 に約 $3 \mathrm{~cm}$ 程度盛り、播種後の芝の成長状況を観察した。 なお、植栽ポットの設置場所は Photo. 1 に示すように、 実験棟南面に隣接する骨材ヤードの土間コンクリート 上とし、培養土の流出を防ぐために試験体側面の 4 面 に合板をせき板として設置した。また、雨天時以外は 1 日 1 回灌水を行った。

\section{3. 実験結果および考察}

\section{1 空隙率および圧縮強度試験結果}

Table 3 に各種ポーラスコンクリートの空隙率および 圧縮強度試験の測定值を示す。また、Fig. 3 に各供試体 に対する空隙率、圧縮強度および表乾密度の比較を示す。

空隙率に関して、骨材に砕石 5 号を使用したものは 目標空隙率 30 \%にほぼ近い值が得られているが、保水 材として木炭粉末および PS 灰を混入した場合に若干空 隙率が減少している。目標空隙率を $20 \%$ とした廃ガラ ス発泡骨材、ゼオライト骨材 A および B を用いたもの は、ゼオライト骨材 B についてはほぼそれに近い值が 得られているが、廃ガラス発泡骨材の場合は、それ自体 に開放空隙量が多いために目標空隙率の約 2 倍の実測 值になっている。また、ゼオライト骨材 A の場合には、 
Table 3 Test results of void ratio and compressive strength

\begin{tabular}{|c|c|c|c|}
\hline \multirow{2}{*}{$\begin{array}{c}\text { Type of } \\
\text { Aggregate }\end{array}$} & \multicolumn{2}{|c|}{ Void ratio $(\%)$} & \multirow{2}{*}{$\begin{array}{c}\text { Compressive } \\
\text { strength } \\
\left(\mathrm{N} / \mathrm{mm}^{2}\right)\end{array}$} \\
\hline & $\begin{array}{l}\text { Total } \\
\text { void }\end{array}$ & $\begin{array}{c}\text { Continuous } \\
\text { void }\end{array}$ & \\
\hline $\begin{array}{l}\text { Crushed } \\
\text { stone }\end{array}$ & 34.3 & 33.8 & 7.37 \\
\hline $\begin{array}{l}\text { Crushed } \\
\text { stone }+ \\
\text { Charcoal }\end{array}$ & 31.8 & 31.1 & 10.9 \\
\hline $\begin{array}{c}\text { Crushed } \\
\text { stone + PS } \\
\text { ash }\end{array}$ & 27.5 & 25.6 & 9.04 \\
\hline $\begin{array}{c}\text { Waste glass } \\
\text { foam }\end{array}$ & 41.0 & 38.1 & 1.28 \\
\hline Zeolite B & 19.4 & 13.1 & 5.16 \\
\hline Zeolite A & 10.3 & 7.11 & 9.05 \\
\hline
\end{tabular}

粒径範囲が細骨材であるために、空隙がセメントペース トにより閉塞されやすく目標空隙率よりも逆に小さい值 となっている。現行の空隙率試験方法を廃ガラス発泡体 のように内部空隙量が多い骨材に適用すると、測定され る空隙率に骨材内部の空隙を含み、植生空間として要求 される骨材粒子間隙の正味の空隙率を正確に測定するこ とができないように思われる。

圧縮強度に関して、骨材に砕石 5 号を用いたものは 約 8 $10 \mathrm{~N} / \mathrm{mm}^{2}$ 程度の值が得られ、保水材として木炭 粉末やPS 灰を混入した場合には、外割混入により空隙 が充填されるために無混入と比べて、圧縮強度は増加し ている。また、廃ガラス発泡骨材を用いたものは空隙率 が大きいだけでなく、骨材強度もかなり小さいために、 他の供試体に比べて圧縮強度がかなり小さい值となって いるが、表乾密度は $1.0 \mathrm{~g} / \mathrm{cm}^{3}$ 未満と超軽量であること が分かる。なお、屋上緑化における土壤工法では屋根久 ラブの積載荷重が特に問題であり、廃ガラス発泡骨材 ポーラスコンクリートの使用により積載荷重の大きな軽 減がはかられることは大きなメリットであり、強度が小 さいといっても土壤強度よりも十分に大きく、屋上緑化 基盤への用途に特に問題となることはないと考えられ る。

ここで、既報 ${ }^{3)}$ の次式に示す圧縮強度の推定式によ る計算結果と実験結果との比較を Fig. 4 に示す。計算 值に対する実験值の比の平均值は 0.930、変動係数は $65.5 \%$ とばらつきはかなり大きいものの、各種骨材を 用いたポーラスコンクリートの圧縮強度をある程度推定 できるものと考えられる。

$$
\begin{array}{r}
F_{c}=12.6 k\{0.48(C / W)-0.87\} e^{0.61 D d-0.06 V a} \\
\text { ここに、 } F_{c}: \text { 圧縮強度 }\left(\mathrm{N} / \mathrm{mm}^{2}\right) \\
k: \text { セメント種類による影響係数 } \\
\\
\quad(\text { 高炉セメント B 種 }: 1.0)
\end{array}
$$
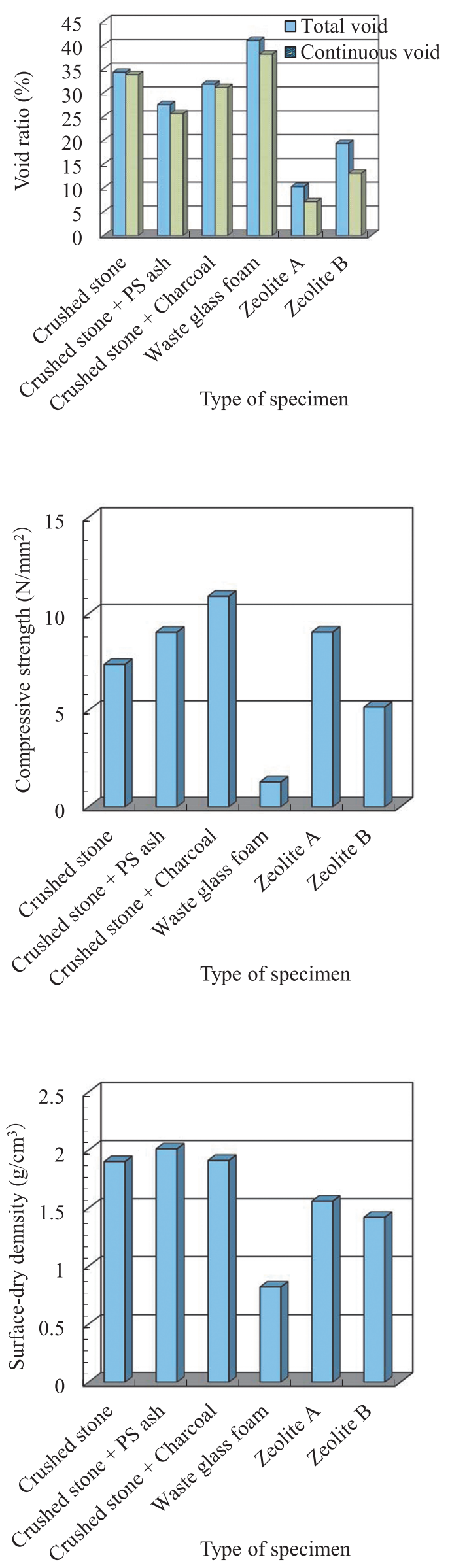

Fig. 3 Measurements of void ratio, compressive strength and surface-dry density 


$$
\begin{aligned}
C / W & : \text { セメント水比 } \\
D d & : \text { 骨材絶乾密度 }\left(\mathrm{g} / \mathrm{cm}^{3}\right) \\
V a & : \text { 空隙率 }(\%)
\end{aligned}
$$

なお、セメント水比 $(C / W)$ には、Table 2 に示す 水セメント比 $(W / C)$ の逆数、骨材絶乾密度 $(D d)$ には、 Table 1 に示す測定值、空隙率 $(V a)$ には、Table 3 に示 す全空隙率の測定值をそれぞれ用いた。

\section{2 保水性試験結果}

Fig. 5 に各試験体の初期保水量 $\left(\mathrm{g} / \mathrm{cm}^{3}\right)$ を、Fig. 6 に は赤外線ランプ照射による保水率 $(\%)$ の経時変化を示す。 ポーラスコンクリートの初期保水量は、骨材にゼオラ イト骨材使用>廃ガラス発泡骨材使用>砕石 5 号使用 の順に大きく、ゼオライト骨材および廃ガラス発泡骨材 の吸水率はともに約 $40 \%$ 強と同程度であるが、初期保 水量はゼオライト骨材使用の方が廃ガラス発泡骨材使用 よりもかなり大きくなっている。また、廃ガラス発泡骨

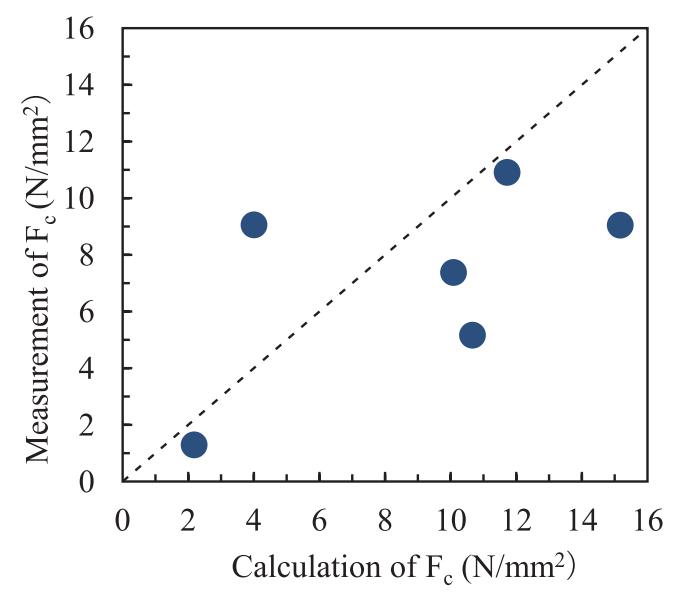

Fig. 4 Comparison of calculation and measurement of compressive strength

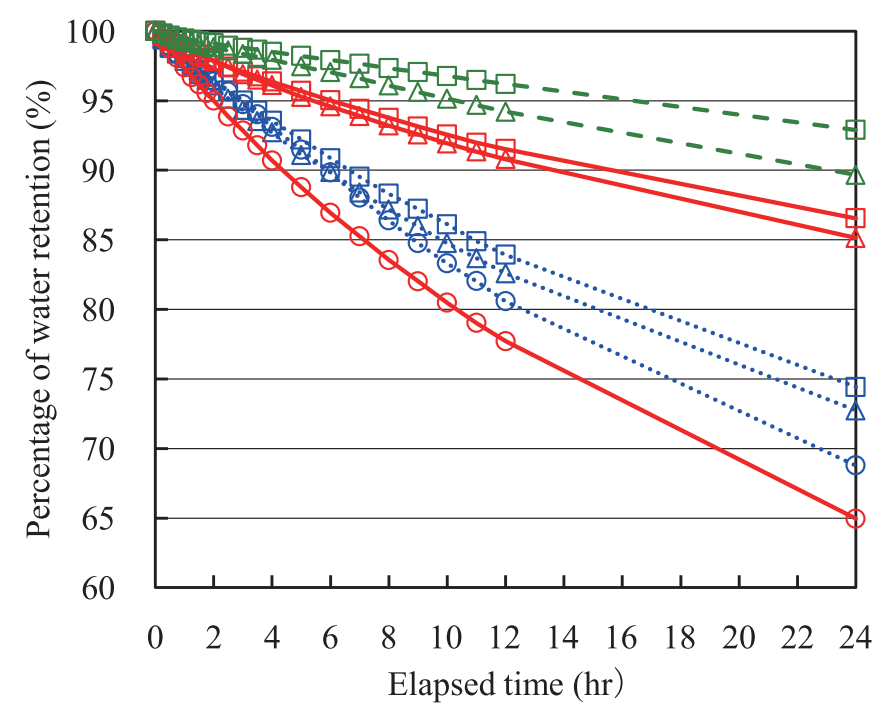

....... Crushed stone

$\cdots \Delta \cdots$ Crushed stone + PS ash

....... Crushed stone + Charcoal

$\multimap$ Waste glass foam

$\triangle$ Waste glass foam + Zeolite A

$\square$ Waste glass foam + Zeolite B

$-\Delta-$ Zeolite A

$-\boxminus-$ Zeolite B

Fig. 6 Relationship between elapsed time (hr) and water retention (\%) 


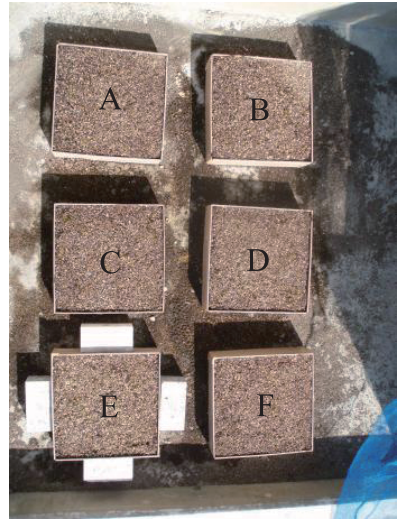

1 week after seeding

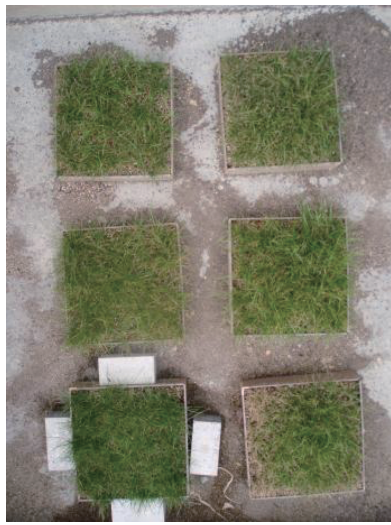

2 months after seeding

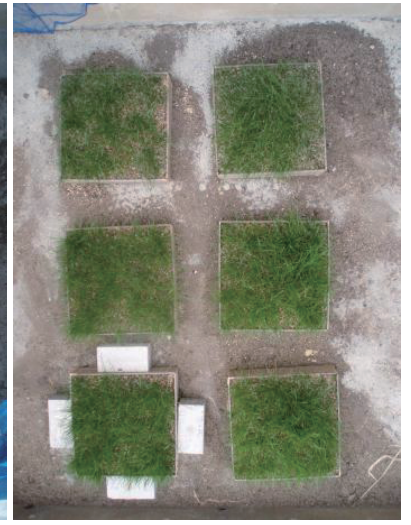

1 month after seeding

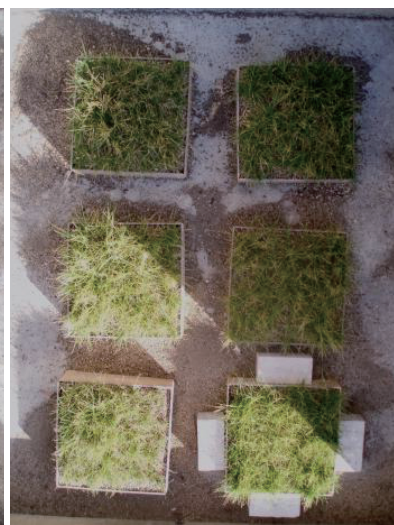

3 months after seeding
A: Waste glass foam + Zeolite B

B: Crushed stone + Charcoal

$\mathrm{C}$ : Waste glass foam

D: Crushed stone + PS ash

E: River sand bedding (for comparison)

F: Crushed stone

Photo. 2 Transition of growth of the turf

ガラス発泡骨材使用の順に大きく、廃ガラス発泡骨材 ポーラスコンクリートの保水率が予想外に小さいことが 分かる。また、砕石 5 号を用い、保水材として PS 死や 木炭粉末を混入した場合には無混入と比べて保水率は向 上している。ところで、廃ガラス発泡骨材ポーラスコン クリートの保水率が小さいのは、廃ガラス発泡骨材自体 の空隙径や開放空隙量が大きく、内部水分が蒸散しやす い空隙構造のためと考えられるが、ゼオライト骨材ポー ラスコンクリートを保水層として 2 層構造板とするこ とによって、保水能力がかなり向上することが分かる。

以上の結果について、試験体ごとに空隙率や空隙径が 異なるために、使用骨材のみの影響として本実験の範囲 内では直接の比較はできないものと考えられるが、ゼオ ライト骨材ポーラスコンクリートの場合には、他の試験 体との比較で、空隙率が小さいのに初期保水量や保水率 が大きいのは、ゼオライト骨材の粒径やそれ自体の空隙 構造に起因している、また廃ガラス発泡骨材ポーラスコ ンクリートの場合には、砕石ポーラスコンクリートとの

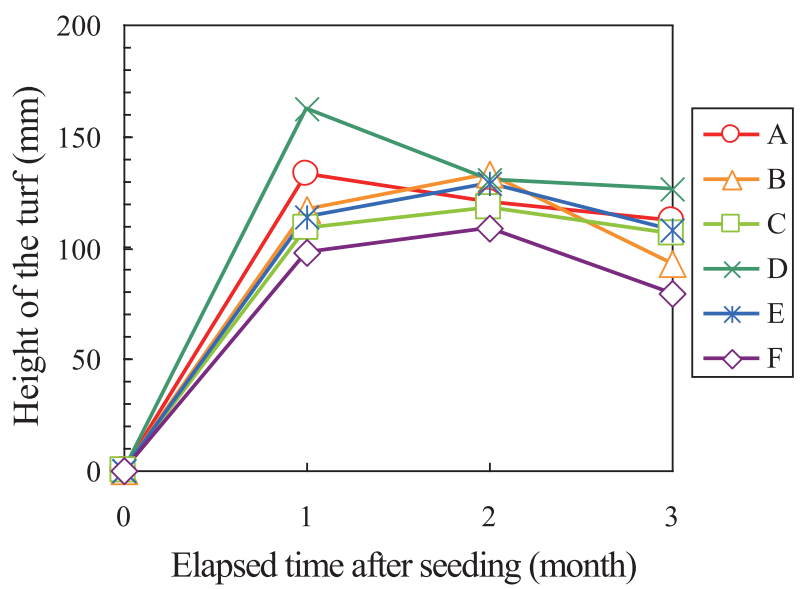

Fig. 7 Relationship between elapsed time after seeding and height of the turf

比較で、空隙率が大きいので初期保水量は大きいが、保 水率が小さいのは、廃ガラス発泡骨材自体の空隙構造に 起因しているものとそれぞれ推察される。

\section{3 芝植栽試験結果}

Photo. 2 に播種後 1 週間、 1 ケ月、2 ケ月および 3 ケ 月時点での芝の成長状況を示す。また、Fig. 7 に芝の草 丈の経時変化を示す。なお、芝の草丈の測定は、試験体 表面から無作為に抽出した 10 本程度の草丈の測定值の 平均值を求め、その值について試験体側面から見た全体 の草丈と大きな差異がないことを確認する方法によっ た。試験体間の差異は、播種後 1 ケ月時点で顕著であり、 それ以降で試験体間に大きな差異はないが、3 月を通 じて砕石 5 号骨材ポーラスコンクリートにおける芝草 丈の成長量が最小であることが分かる。また、播種後 1 ケ月時点では PS 灰混入砕石 5 号骨材コンクリートが 最大で、次いで廃ガラス発泡骨材ポーラスコンクリー トとゼオライト骨材 B ポーラスコンクリートの 2 層構 造板の芝草丈の成長量が大きくなっており、前者につい ては灰による芝の成長促進作用が、後者については高い 保水性能が関係しているのではないかと思われる。ただ し、本実験の範囲内では、ポーラスコンクリートの保水 性が芝植生効果に及ぼす影響を定量的に考察するには至 らず、今後さらに検討を要するものの、砕石 5 号骨材ポー ラスコンクリートとの比較で芝成長量に一様の効果が認 められた。

\section{4. まとめ}

本研究ではリサイクル資材による生物対応型エコマテ リアルの開発を主眼に、屋上緑化基盤としての廃ガラス 発泡軽量骨材を用いたポーラスコンクリートの基礎物性 試験ならびに芝の植生試験を行い、その適用性について 実験的検討を行った。その結果として廃ガラス発泡骨材 ポーラスコンクリートは、骨材強度が小さいためにポー ラスコンクリートの圧縮強度はかなり小さくなるが、超 軽量化がはかられ、屋上緑化基盤として積載荷重の軽減 
に有効であること、また廃ガラス発泡骨材ポーラスコン クリート単独では、骨材自体に開放空隙量が多いために 水分の蒸散量が大きくなり、保水性能に劣るが、保水 性能の大きなゼオライト骨材ポーラスコンクリートを 2 層構造板とすることで保水能力の大きな改善がはかられ ること、さらに芝の植生試験結果では砕石 5 号骨材ポー ラスコンクリートとの比較で芝草丈の成長量の増加に効 果を有することなどが分かった。

ただ、ポーラスコンクリートの保水性能が芝の植生効 果に及ぼす影響については、本研究の範囲内ではそれを 意図する直接の実験的検討を行っていないために、今後 さらに検討を要するものと考えられる。

\section{謝辞：}

本研究は NPO 法人廃棄物再資源化研究会(理事長 : 三井宜之熊本大学名誉教授)の研究支援の下で実施され たものであり、研究会会員の皆様に多大なご協力をいた
だきました。また、実験にあたっては、当時熊本大学工 学部甲斐定夫技術専門職員、当時熊本大学大学院自然科 学研究科博士前期課程河上晃一郎、当時同大学工学部環 境システム工学科卒研生衛藤千晴、松本淳、森崎洋輔、 米重大輔諸氏の協力をいただきました。ここに記して謝 意を表する。

\section{参考文献 :}

1） 日本コンクリート工学協会：ポーラスコンクリート の設計・施工法の確立に関する研究委員会報告書 (2003)

2）インターロッキングブロック舗装技術協会：保水性 舗装用コンクリートブロックの品質規格（2005）

3）大谷俊浩ほか：ポーラスコンクリートの圧縮強度推 定式の構築に関する研究、日本建築学会構造系論文 集、第 590 号、pp. 25-30（2005）

\title{
APPLICATION OF POROUS CONCRETE WITH WATER RETENTION MADE OF WASTE GLASS FOAM TO PLANTING BASE
}

\author{
Kiyoshi MURAKAMI*1, Koji TAKEDA*1, Makoto YAMAGUCHI*1 and Ayumi SATO*1
}

*1 KUMAMOTO UNIVERSiTY, Graduate School of Science and Technology (2-39-1, Kurokami, Chuo-ku, Kumamoto-shi, Kumamoto 860-8555, Japan)

\begin{abstract}
For the purpose of developing an environmentally friendly material with bio-adoptability using recycle materials, fundamental properties and planting growth of porous concretes with waste glass foam as roof planting base were tested, and its applicability was experimentally investigated. Fundamental properties are void ratio, compressive strength and water retention by infrared irradiation. As a result, it was shown that porous concretes using waste glass foam aggregate have low compressive strength but super-light weight which is effective in reducing roof carrying load, and a porous concrete with two-layers composed of waste glass foam and zeolite aggregates has some effect in planting growth of the turf because of its high water retention.
\end{abstract}

KEY WORDS : Roof planting, Waste glass foam aggregate, Zeolite aggregate, Void ratio, Compressive strength, Water retention, Planting growth 